\title{
Construction of Soil Metagenomic Library to Obtain Recombinant Clones with an Indigenous Lipase Activity
}

\author{
Pembuatan Perpustakaan Metagenom Tanah untuk Mendapatkan Klon Rekombinan \\ dengan Aktivitas Lipase Indigenous
}

\author{
Agus Hery Susanto*, Hendro Pramono, Puji Lestari \\ Faculty of Biology, Jenderal Soedirman University \\ Jalan Adipura VI/235 Purwosari Purwokerto 53151 \\ E-mail: susanto1408@yahoo.co.id *Penulis untuk korespondensi
}

\begin{abstract}
Abstrak
Penelitian ini bertujuan untuk mengonstruksi perpustakaan metagenom tanah dari sekitar lokasi industri pengolahan minyak kelapa di Kabupaten Banyumas, Jawa Tengah, dalam upaya mendapatkan klon rekombinan dengan aktivitas lipase indigenuos. Penelitian dilakukan di Laboratorium Genetika, Fakultas Biologi, Universitas Jenderal Soedirman mulai bulan Mei hingga Desember 2006. Secara umum tahapan penelitian terdiri atas ekstraksi dan pemurnian DNA tanah, isolasi pUC19, pemotongan DNA tanah, pemotongan dan defosforilasi pUC19, ligasi fragmen-fragmen DNA tanah ke dalam pUC19 untuk menghasilkan molekul DNA rekombinan, dan transformasi sel inang $E$. coli JM109 menggunakan molekul DNA rekombinan yang diperoleh untuk mengonstruksi perpustakaan metagenom tanah. Pemotongan DNA tanah menghasilkan fragmen-fragmen yang sebagian besar berukuran lebih kurang 5 kb sehingga gen lipase dimungkinkan untuk dibawa di dalamnya. Transformasi sel inang $E$. coli JM109 memperlihatkan efisiensi $1.7 \times 10^{5}$ cfu/ $\mu \mathrm{g}$ plasmid. Di antara koloni-koloni yang diperoleh, terdapat 102 koloni berwarna putih, yang menunjukkan keberadaan molekul DNA rekombinan. Koloni putih ini dapat digunakan sebagai materi untuk skrining klon rekombinan dengan aktivitas lipase.
\end{abstract}

Kata kunci: perpustakaan metagenom tanah, pUC19, E. coli JM109, lipase indigenous

Diterima: 02 Februari 2009, disetujui: 03 Agustus 2009

\section{Introduction}

Lipases (E.C. 3.1.1.3) are enzymes catalyzing hydrolysis of lipid or triacylglycerol into glycerol and free fatty acids. These enzymes usually exhibit broad substrate specificity and degrade acyl p-nitrophenyl esters, Tweens and phospholipids, often with positional selectivity, stereoselectivity, and chain length selectivity. They have been recognized as very useful biocatalysts because of their wide-ranging versatility in industrial applications (Saxena et al., 2003; Gupta et al., 2004).

To obtain microbial lipases by means of molecular approach are commonly carried out by exploring one of a certain strain of microorganism. With this strategy, it will, however, result in a considerable loss of microorganisms having potential to produce lipases as not all of them could be cultivated using standard techniques known so far (Triana et al., 2007). Only $0.1 \%$ of approximately $10^{7}$ cells in a gram of soil sample could be cultivated (Kellenberger, 2001).

Recently, a new approach of accessing genetic sources from environmental samples, particularly soil, without need of microorganism cultivation, has been developed. In the so-called as metagenomic approach, the whole genomes of all microorganisms presenting in a certain 
habitat are directly cloned to provide a metagenomic library as source of materials to screen for genes of interest (Lorenz and Schleper, 2002).

Soils exposed to coconut oil effluent in a long period of time have potential to contain microorganisms which produce lipases, so that such types of soils can be used to explore lipase genes employing a metagenomic approach. Several coconut oil home industries exist in Banyumas regency, Central Java, from which soil samples could be taken as DNA sources in the construction of metagenomic library to obtain lipase genes. Following this way, indigenous microbial lipases will be expectantly acquired. This study was aimed to construct a soil metagenomic library in Escherichia coli JM109 cell hosts to provide recombinant clones which will be screened further for an indigenous lipase activity.

\section{Materials and Methods}

This study was conducted in the Laboratory of Genetics, Biology Faculty, Jenderal Soedirman University from May to December 2006 involving some consecutive steps, i.e. soil sampling, soil DNA extraction and purification, pUC19 plasmid isolation, partial digestion of soil DNA, digestion and dephosphorilation of pUC19, ligation of soil DNA fragments into linear pUC19 to produce recombinant DNA molecules, and transformation of E. coli JM109 cell hosts with the recombinant DNA molecules to construct a soil metagenomic library.

Soil sample of approximately $5 \mathrm{~g}$ was taken from around a location of coconut oil home industry in Banyumas regency, Central Java at $15 \mathrm{~cm}$ depth using sterile spatula after that it was put into a sterile plastic bag. This sample was then stored at $4^{\circ} \mathrm{C}$ until DNA extraction was carried out.

DNA was extracted and purified using Power Soil DNA Extraction Kit (MoBio, USA). On the other hands, pUC19 was isolated from E. coli JM109 using Wizard Miniprep Kit.

The purified soil DNA was partially digested with $B a m \mathrm{HI}$ in which the reaction was incubated at $37^{\circ} \mathrm{C}$ for 30 minutes. The enzyme was inactivated at $65^{\circ} \mathrm{C}$ for 15 minutes. At the same time pUC19 was also cut with BamH I by incubating the reaction at $37^{\circ} \mathrm{C}$ for 60 minutes prior to inactivation at $65^{\circ} \mathrm{C}$ for 15 minutes. To remove the remaining $B a m \mathrm{H}$ I from both soil DNA and pUC19 reaction of digestion, purification was made using Wizard DNA Purification Kit. Then, the linear pUC19 was dephosphorilated with calf intestinal alkaline phosphatase (CIAP) provided by Promega. To remove the remaining CIAP from the dephosphorilation reaction, Wizard DNA Purification Kit was also used.

Ligation of soil DNA fragments into the linear pUC19 was conducted using T4 DNA ligase with overnight incubation at $4^{\circ} \mathrm{C}$. This ligation mixture was purified from the residual T4 DNA ligase using Wizard DNA Purification Kit. The recombinant pUC19s generated was then used to transform E. coli JM109 competent cells.

To achieve the highest efficiency of transformation, E. coli JM109 competent cells were incubated at $4^{\circ} \mathrm{C}$ for 16 hours. As much as $200 \mu \mathrm{l}$ competent cell cultures was added with $10 \mu 1$ recombinant pUC19 after the heat shock was immediately applied at $42^{\circ} \mathrm{C}$ for 50 seconds. Transformation of E. coli JM109 using intact pUC19 was also given as control. The transformed colonies were plated onto Lagar medium containing ampicillin and $\mathrm{X}$ gal/IPTG.

Both the number of all colonies formed and that of white colonies observed were counted. The efficiency of transformation was calculated as the ratio of E. coli JM109 colonies formed (cfu) to recombinant pUC19s added $(\mu \mathrm{g})$.

\section{Results and Discussion}

Soil DNAs of about the same quality and concentration are resulted from twice extraction and purification as shown in Figure 1. The electrophoretic bands indicated that the DNAs obtained were relatively free from humic acids, which frequently contaminate the extracted soil DNA and may disturb the following enzymatic manipulation processes (Ogram et al., 1987; Porteous and Armstrong, 
1991; Endo et al., 1992; Jacobsen and Rasmussen, 1992; Picard et al., 1992; Smalla et al., 1993; Volossiouk et al., 1995; Zhou et al., 1996). On the other hands, post-extraction DNA purification to remove humic acids often results in fewer soil DNA as well as physical DNA degradation.

Comparing the fluorescence of soil DNA bands and that of Hind III cut $\lambda$ marker we estimated the soil DNA concentration was approximately $100 \mathrm{ng} / \mu \mathrm{l}$. Because the entire DNAs from $0.25 \mathrm{~g}$ soil samples were eluted in a volume of $100 \mu \mathrm{l}$, it could be said that the extraction and purification yielded $40 \mu \mathrm{g}$ DNA $\mathrm{g}^{-1}$ soil. This much exceeded the yield of soil DNA extraction and purification after Wechter et al., (2003), i.e. $5.22 \mu \mathrm{g}^{\mathrm{DNA}} \mathrm{g}^{-1}$ soil, with the same time length of processing ( 2 hours).

The DNA band in the respective lane showed that the DNA was not subject to physical fragmentation, or in other words, intact lipase gene might be carried in it and the soil DNA could be proceded to the next treatment, i.e. partial digestion using a restriction enzyme. The results of partial digestion using BamHI could be seen in Figure
2 lane 4 and 5. Most DNA fragments generated seemed to be of approximately $5 \mathrm{~kb}$, so that they could be expected to contain intact lipase genes. Henne et al., (2000) reported that recombinant clones showing lipase activity could be obtained by screening a soil metagenomic library having insert size of 5 to 8 $\mathrm{kb}$.

The pUC19 isolated from E. coli JM109 was visualized in Figure 2 lane 1, while the results of digestion and dephosphorilation of this plasmid could be seen in Figure 2 lane 2. It was shown that pUC19 has been subject to complete digestion and could be used as cloning vector to bear the partially digested soil DNA fragments. Comparing the fluorescence of linear pUC19 and that of Hind III cut $\lambda$ marker we estimated the plasmid concentration of approximately $30 \mathrm{ng} / \mu \mathrm{l}$.

The purification of digestion mixture, both of soil DNA and of pUC19, resulted in the fragments that were visualized in Figure 3. From the electrophoretic bands, it could be said that the recovery of both pUC19 dan soil DNA fragments was sufficiently high that they could used in the ligation process.

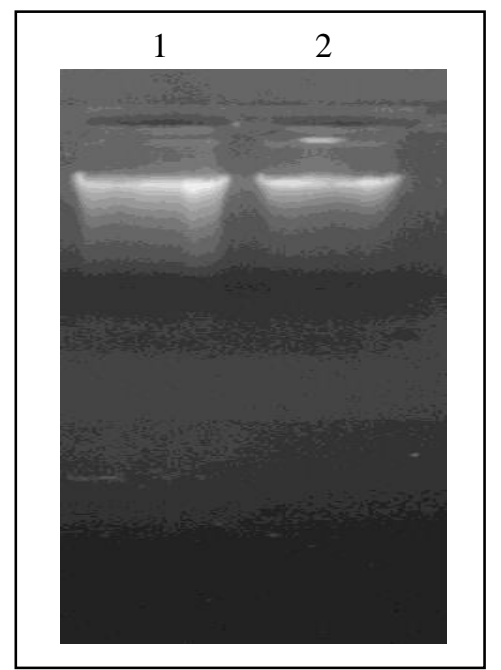

Figure 1. Electrophoregram of extracted and purified soil DNAs

Notes: 1 . Soil DNA of first extraction

2. Soil DNA of second extraction 


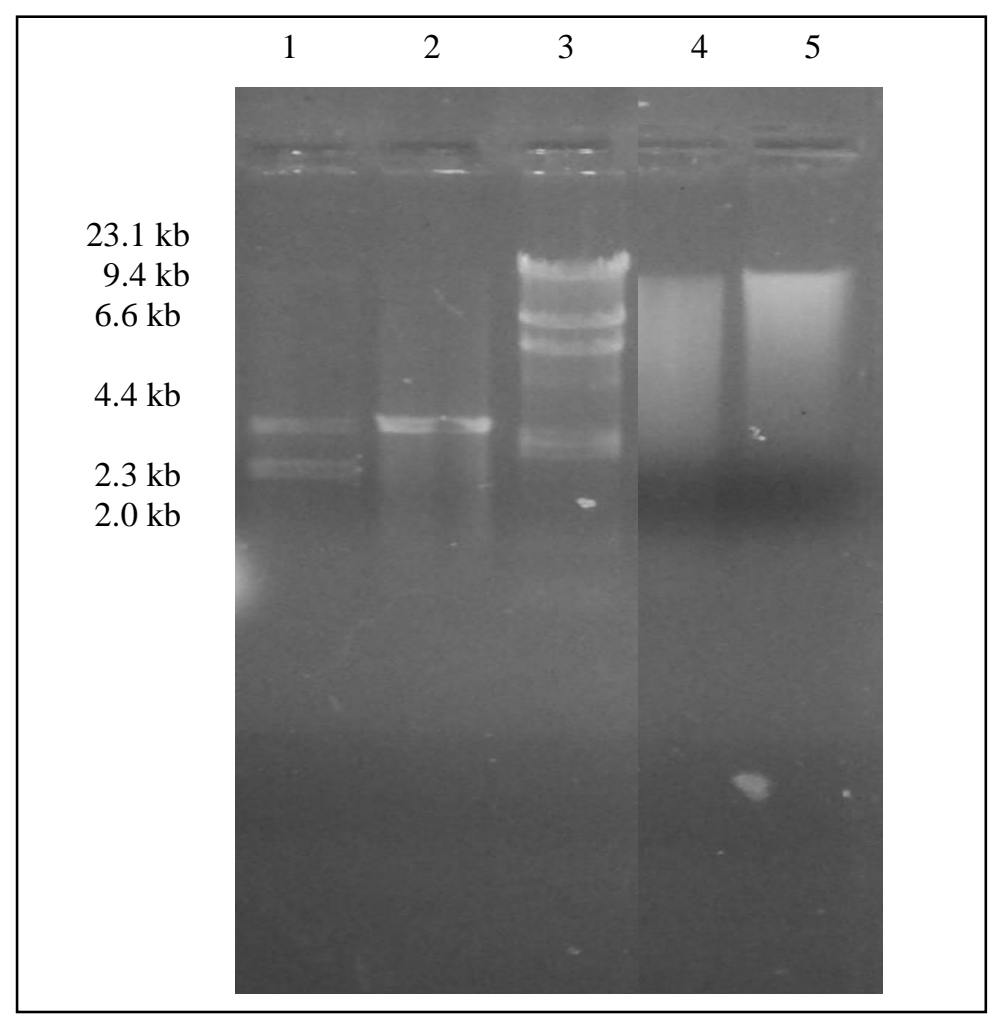

Figure 2. Electrophoregram of pUC19 and soil DNA digestion.

Notes: 1. Intact pUC 19

2. pUC 19 cut with BamH I

3. Hind III cut $\lambda$ marker

4. First extracted soil DNA cut with BamH I

5. Second extracted soil DNA cut with BamH I

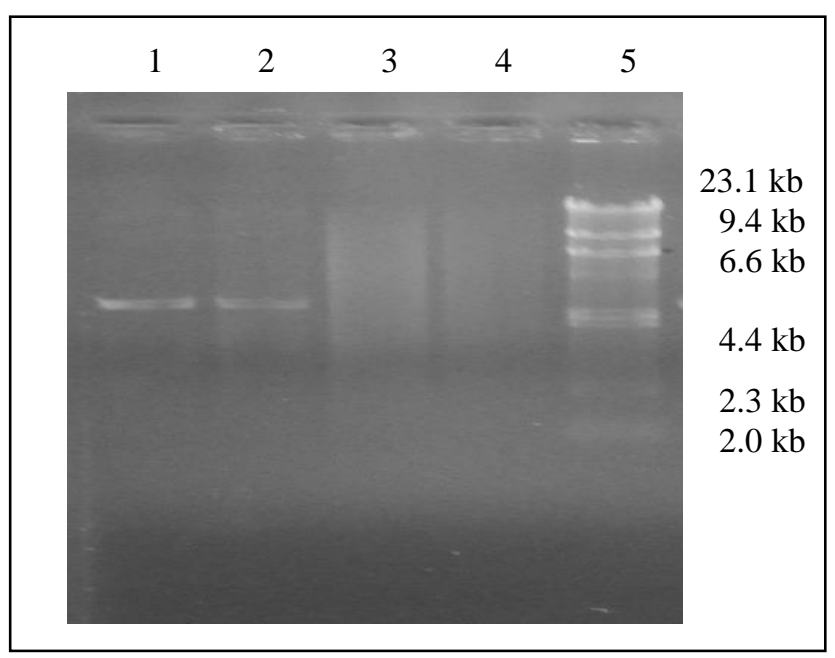

Figure 3. Electrophoregram of linier purification pUC19 and soil DNA digestion.

Notes: 1. First purified linear pUC19

2. Second purified linear pUC19

3. First purified soil DNA fragments

4. Second purified soil DNA fragments

5. Hind III cut $\lambda$ marker 
The recombinant pUC19s as a result of ligation with soil DNA fragments were directly used to transform E. coli JM109 competent cells. In $20 \mu \mathrm{l}$ ligation mixture, as much as $3 \mu \mathrm{l}$ (90 ng) pUC19 was used resulting in the plasmid concentration of $4.5 \mathrm{ng} / \mu \mathrm{l}$. From this mixture, $5 \mu \mathrm{l}\left(22.5 \times 10^{-3} \mu \mathrm{g}\right)$ pUC19 was used to transform E. coli JM109 cells.

As many as 102 white colonies and 848 blue colonies were observed in L-agar medium containing ampicillin and X-gal/IPTG. On the other hands, the transformation control with intact pUC19 resulted in 2,540 blue colonies. Because the transformant culture plated was $250 \mu \mathrm{l}$ of a total volume of $1 \mathrm{ml}$, the efficiency of transformation in the control was 2,540 x 4 $\mathrm{cfu} / 22.5 \times 10^{-3} \mu \mathrm{g}=4.5 \times 10^{5} \mathrm{cfu} / \mu \mathrm{g}$, while using recombinant pUC19 was $950 \mathrm{x} 4 \mathrm{cfu} / 22.5$ x $10^{-3} \mu \mathrm{g}=1.7 \times 10^{5} \mathrm{cfu} / \mu \mathrm{g}$. Transformation is said to be efficient when it reaches a value of $10^{5} \mathrm{cfu} / \mu \mathrm{g}$ (Sambrook et al., 1989).
The pUC19s were isolated from both white and blue colonies as shown in Figure 4. The difference in the band pattern of pUC19s from white and blue colonies indicated that pUC19s from white colonies bear soil DNA fragments. Therefore, screening for lipase activity among the white colonies could be further employed.

\section{Conclusion}

It is concluded that metagenomic DNA could be isolated and purified from soil exposed to coconut oil effluent around a home industry location in Banyumas regency, Central Java. A metagenomic library from the soil DNA could then be constructed in E. coli JM109 cell hosts to provide recombinant clones which will be screened further for an indigenous lipase activity.

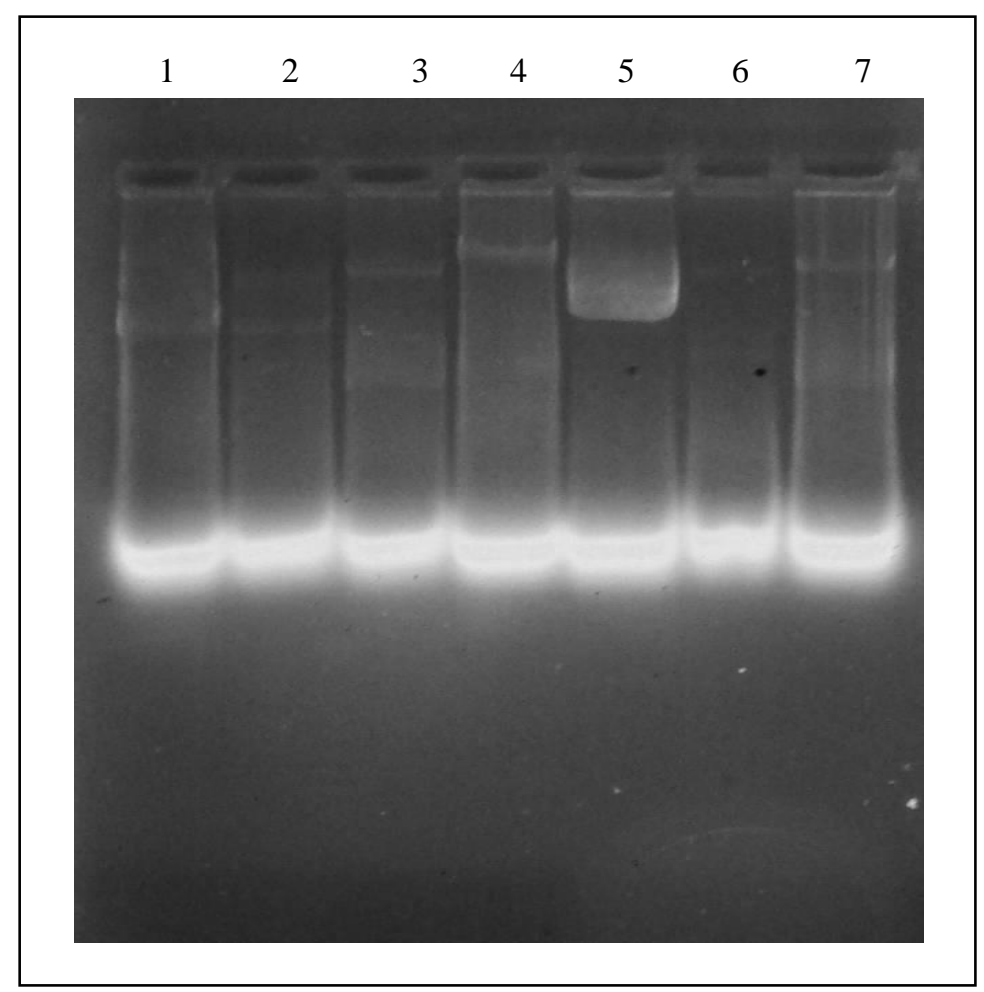

Figure 4. Electrophoregram of isolated pUC19s from E. coli JM109 transformants

Notes: 1 - 5 pUC19s from white colonies 6 - 7 pUC19s from blue colonies 


\section{Acknowledgement}

We address our thanks to Hibah Bersaing Project XIV/I year 2006 for financial support provided.

\section{References}

Endo, G., Koseki, T. and Oikawa, E. 1992. Quantitative detection of genetically-modified microorganisms by the PCR-MPN method. FEMS Symp. Federation of European Microbiol. Soc. 63: 221-223.

Gupta, R., Gupta, N. and Rathi, P. 2004. Bacterial lipases: an overview of production, purification and biochemical properties. Appl. Microbiol. Biotechnol. 64: 763-781.

Henne, A., Schmitz, R.A., Bomeke, M., Gottschalk, G. and Daniel, R. 2000. Screening of environmental DNA libraries for the presence of genes conferring lipolytic activity on Escherichia coli. Appl. Environ. Microbiol. 66 (7): 3113-3116.

Jacobsen, C.S. and Rasmussen, O.F. 1992. Development and application of a new method to extract bacterial DNA from soil based on separation of bacteria from soil with cation-exchange resin. Appl. Environ. Microbiol. 58: 24582462.

Kellenberger, E. 2001. Exploring the unknown: the silent revolution of microbiology. EMBO Rep. 2: 57.

Lorenz, P. and Schleper, C. 2002. Metagenome: a challenging source of enzyme discovery. $J$. Mol. Catal. B Enzym. 19: 13-19.

Ogram, A., Sayler, G.S. and Barkay, T. 1987. The extraction and purification of microbial DNA from sediments. J. Microbiol. Methods. 7: 5766 .
Picard, C., Ponsonnet, C., Paget, E., Nesme, X. and Simonet, P. 1992. Detection and enumeration of bacteria in soil by direct DNA extraction and polymerase chain reaction. Appl. Environ. Microbiol. 58: 2717-2722.

Porteous, L.A. and Armstrong, J.L. 1991. Recovery of bulk DNA from soil by a rapid, small-scale extraction method. Current Microbiol. 22: 345-348.

Sambrook, J., Fritsch, E.F. and Maniatis, T. 1989. Molecular Cloning: laboratory manual $2^{\text {nd }} e d$. Cold Spring Harbor Laboratory Press, Spring Harbor, N.Y.

Saxena, R.K., Sheoran, A., Giri, B. and Davidson, W.S. 2003. Review: purification strategies for microbial lipases. J. Microbiol. Methods. 52: $1-18$.

Smalla, K., Cresswell, N., Mendonca-Hagler, L.C., Wolters, A. and van Elsas, J.D. 1993. Rapid DNA extraction protocol from soil for polymerase chain reaction mediated amplification. J. Appl. Bacteriol. 74: 78-85.

Triana, E. dan Nurhidayat, N. 2007. Seleksi dan Identifikasi Lactobacillus Kandidat Probiotik Penurun Kolesterol Berdasarkan Analisis Sekuen 16S RNA. Biota 12 (1): 55-60.

Volossiouk, T., Robb, E.J. and Nazar, R.N. 1995. Direct DNA extraction for PCR mediated assays of soil organisms. Appl. Environment. Microbiol. 61: 3972-3976.

Wechter, P., Williamson, J., Robertson, A. and Kluepfel, D. 2003. A rapid, cost-effective procedure for the extraction of microbial DNA from soil. World J. Microbiol. Biotechnol. 19: 85-91.

Zhou, J., Bruns, M.A. and Tiedje, J.M. 1996. DNA recovery from soils of diverse composition. Appl. Environ. Microbiol. 62 (2): 316-322. 